\title{
The Interracial Theatre of 'Strip Tents' in Travelling Shows: Spaces of Sexual Desire in Southeastern Australia, 1930s-1950s
}

\section{KATE HUNTER}

By the end of the nineteenth century agricultural shows (what in the American tradition are called 'fairs'), were well established in Australia. An enduring symbol of agricultural progress and rural modernity, they became in the twentieth century a vehicle for the professionalization of agriculture and the evolution of European farm women's political organizations. ${ }^{1}$ Characterized as such, they are unlikely sites of interracial intimacy yet agricultural shows in rural Australia, and the professional touring shows that often accompanied them, were shared spaces of performance and spectatorship. ${ }^{2}$ Aboriginal performers, boxers, rodeo-riders and spectators were present at these shows alongside non-indigenous farmers, pastoralists and their livestock, as well as sponge-cakes. Agricultural shows involved a series of stages and a continuous programme of events throughout the day. In general the main arena featured displays of farming life and skills, ranging from horse events and livestock competitions through to arrangements of entries in categories of baking and domestic arts.

Away from this central forum were the sideshows: smaller, less orthodox and socially acceptable displays that were nonetheless enormously entertaining. Describing the sideshows at a provincial show in 1931, a reporter for the Brisbane Courier remarked that '[p]roprietors of these mysteries, like Arabs, crept up in the night, and in the morning a mushroom crop of multi-coloured tents set palpitating the hearts of youngsters'. ${ }^{3}$ Sideshows were regarded as mysterious, exotic, nomadic, and spacially as well as socially outside of the mainstream. Part of their extraordinary character was that they were multi-racial spaces both in the composition of the acts and in their audiences. Australian historians Richard Broome and Alick Jackomos have documented the presence of indigenous boxers on the show circuit as well as acts from China and Africa. ${ }^{4}$ The Queenslander, an illustrated newspaper, described 'the merry land of the sideshows' at the Brisbane Exhibition in 1929 which featured boxing troupes, midgets, the 'Tagalog Fire Dancers' and glass blowers. ${ }^{5}$ There were many more 'queer shows in Side-show Land', the reporter observed, and readers could 'see what a bright and happy place it is'.

Sideshows usually toured as a group of acts, tests of skill and, increasingly after the Second World War, rides. They travelled according to the timetable of agricultural shows throughout Victoria, New South Wales and southern Queensland. Some sideshow impresarios and their crews also toured separately, especially in the case of boxing troupes or musical acts, converging with other show people (called 'showies' in Australia) at certain times of the year. Amateur and professional rodeo troupes also toured throughout southeastern Australia, sometimes travelling from Sydney to Auckland, taking in New Zealand as part of their show circuit. Sideshow acts were often referred to in newspaper reports of metropolitan or large provincial agricultural shows, making some acts more visible in the historical record than others. Boxing tents and the boxers themselves were occasionally mentioned, but other attractions such as the bar tent and the 'leg show' were invisible in reporting.

Inside the leg-show tent, young women performed a wide variety of burlesque acts: 'the Eastern Snake Girl', 'Vanessa the Undresser', 'Fifi from Tahiti' and many others now lost to the historical record. Most of the performers, too, are now invisible 
to historians. Often these women retired from the stage to other jobs in the show, passing on their act and stage name to a younger woman. There is evidence in the reminiscences of the 'showies' as well as through autobiographies and oral histories, that several of the performers were indigenous women. These Aboriginal performers are visible in partial and tantalizing ways. For example, as boys in 1950s rural New South Wales (NSW), Australian musician Don Walker and his brother used to swim the river in order to sneak into the annual agricultural show. More specifically, they were attempting to sneak into the strip-show tent. The 'barker' (the spruiker out the front of the tent) was billing the attractions as 'Fifi from Tahiti' and 'Gigi from French Polynesia', but Don remarked that the 'girls looked a lot like Australian country town Aboriginal-Irish to me'.

Snatches of sentences, passing remarks and occasional stories reveal glimpses, suggestions and flashes of revelation about Aboriginal women in the leg shows. It is unsurprising that evidence about these women's lives is scarce. They worked in a marginal occupation staged in the transitory and largely hidden world of sideshows. In addition, as historical subjects these women suffer the double invisibility of working in the largely secret world of sexual exchange and being indigenous. Records of indigenous lives in Australia are notoriously poor. Similarly, there is a dearth of evidence about the lives of women involved in sexual exchange. As Ralene Frances has noted about women working as prostitutes in Australia, 'historians find out most about sex workers when they come into contact with the law, either as accused or victim'. ${ }^{7}$ Australian historian Judith Allen, researching and writing in the 1980s, argued that there were good reasons for the paucity of evidence surrounding sexual practices and illegal sexual activity. For the most part, she explained, 'all parties to the secrets of sex have had compelling reasons for silence'. ${ }^{8}$ This was very much the case in the multi-racial sexual world of the leg show: colonial relationships between white men and indigenous women in Australia had been characterized largely by violence, both physical and cultural, creating a powerful motive for silence.

The suggestive nature of the performances also makes audiences a shadowy group. The photographic record of the main show arena, the demography of rural southeastern Australia and evidence from showies' reminiscences and biographies indicate that show audiences were predominantly white ${ }^{9}$ Oral histories and reminiscences of indigenous people however, especially boxers and horsemen, demonstrate that there were Aboriginal spectators at some displays. ${ }^{10}$ Indeed boxer Billy Primmer described the families of black and white boxers sharing 'a pie at the pie cart outside venues' in the 1950s. ${ }^{11}$ Don Walker's remarks also show that 'sneaking in' was a possibility for those not supposed to be there. The audiences in the leg shows were probably multi-racial but European dominated, and probably included youths.

Encounters between non-Indigenous audience members and Indigenous women performers in the leg shows are, therefore, largely invisible moments of interracial intimacy. Few records survive of performers and even fewer of audience members' responses. The entire concept of the sideshow mitigates against a lasting historical archive. Despite and in spite of the paucity of evidence, I argue that the strip tent was a complicated and animated space of sexual desire, glamour, theatricality and deception, a space that operated in seeming contradiction to the larger picture of racial politics of the early twentieth century. Of particular interest is Aboriginal women performers' use of Pacific Island stage names as a device to disguise their Indigenous identity, thus allowing white male audiences to admire and desire them. It was a 
device through which impresarios, performers and audiences colluded to erase one racial past and devise another.

\section{I}

The backdrop to shows and their displays of agricultural success and pastoral pride was the colonial space of southeastern Australia. By the turn of the twentieth century Aboriginal peoples in that region had endured and adapted to between 70 and 110 years of European invasion and immigration. ${ }^{12}$ At the time of Australian Federation in 1901 Aboriginal people were widely considered to be a 'doomed race'. The large numbers of Indigenous groups living in relatively 'traditional' ways in the Northern Territory and northern Western Australia and Queensland were regarded as an anthropological opportunity rather than a contradiction of the dominant racial ideology. ${ }^{13}$ In the southeast, Aboriginal groups had survived dispossession of their lands and their culture in violent circumstances, but their families and communities had been riven and reduced by introduced diseases, including venereal disease that reduced fertility, by the loss of traditional lands and the cultural and religious practices associated with place, and by legislation that confined them to reserves, controlled their education and employment and family life. These processes had been physically, culturally and mentally violent ranging from warfare in the 1840s through to the violence perpetrated on families by welfare policies a century later. Recalling the scene where her cousins were trying to escape 'the Welfare' in the 1940s, NSW Aboriginal woman Joyce Ingram described the children as 'running like scared rabbits. They'd go in the house and they went under the beds and into the cupboards, and the police went in behind them and hauled them out and put them in the car there screaming for their mother.' One cousin who had managed to evade the police gave herself up the next morning when she saw all her siblings had been captured. Ingram stated, 'and that split up the family. The closeness and the relationship of the family was broken. ${ }^{14}$ Sexual violence was an ongoing feature of colonial relations from early frontier wars through to the sexual abuse sustained by Aboriginal children removed from supposedly neglectful black families and placed with supposedly civilized white families. ${ }^{15}$

By the 1920s southeastern Aboriginal people negotiated their dispossession and disenfranchisement in a variety of ways. Aboriginal peoples were employed in the pastoral and farming industries for several reasons: some chose pastoral work as a strategy designed to maintain contact with traditional lands. Government policy around Aboriginal employment also embedded indigenous workers in pastoral industries. ${ }^{16}$ Living off the reserve either as an itinerant labourer or 'camper', which sometimes meant living away from kin, also often resulted in work on stations and farms. Conditions could be poor and wages non-existent, but some measure of autonomy was available through agricultural work. As policies changed around who could live on reserves, young Aboriginal men and women also migrated to the cities where new forms of community were established. Men and women from all of these groups ended up on the show circuit as riders, boxers, ticket sellers and crew, and in the leg show. ${ }^{17}$

Indigenous participation in travelling shows was differentiated by gender. Aboriginal men were visible, skilled and admired participants in several arena shows. Most obviously, they performed in front of mixed audiences (mixed in sex and age, as well as race) in the main rodeo ring. ${ }^{18}$ Their other main arena was that of the boxing tent, where they were part of professional troupes fighting local challengers in front of a male audience that was generally white and adult. ${ }^{19}$ In both of these cases particular 
forms of men's Aboriginality was celebrated: in the case of boxers, Richard Broome has argued that their masculinity and physical power transcended race while they were in the ring. ${ }^{20}$ In the case of rodeo riders, their participation in the workforce of the pastoral industry meant that Aboriginal riders could be classed as 'station blacks' in opposition to 'wild blacks' who had not been assimilated. However, men's Aboriginality was often invoked when discussing their talent with horses. ${ }^{21}$ In both cases, men received admiration from audiences, wages and equal prize monies with non-indigenous riders and boxers. In the case of horsemen, they were also the subject of media attention in both specialized farming and equestrian press, and in regional and metropolitan newspapers.

Aboriginal women also appeared regularly at travelling shows, but they performed in a much less public arena alongside non-indigenous women in the 'leg shows' or strip tent. Information about these women - and they were not all Aboriginal women - is scant; most often all that is recorded are their stage names. For example, in the local history Rodeo at Lang Lang, the 1930s sideshows are listed as including Jimmy Sharman's and Harry Johns' boxing troupes, the bar tent and 'Vanessa the Undresser' and 'Theresa the Stripteaser'. ${ }^{22}$ In impresario Larry Delahunty's shows on the southeastern circuit in the 1950s, "Candy and Sally were the dancing girls. Candy was billed as a hula dancer "direct from Tahiti", although she was part Aborigin[al] who until then had been no further north than Townsville. ${ }^{23}$ Owen Rutherford Lloyd was showing at the Hobart Regatta in the 1940s, 'and on the next pitch was a stripshow ... The Harem, The Dance of the Seven Veils and a few assorted specialties kept those girls busy all the time. There was a Chinese, a black and a blonde. Not a bad class of girl considering, all of them decent types, working hard and not getting much out of it. ${ }^{24}$

Complicating Aboriginal women's performances was their theatrical identities as Pacific Island women. As Don Walker's reminiscence above indicates, Aboriginal women's stage acts usually involved some reference to Pacific identities, albeit in confused and generic ways. Show owners took stage identities very seriously. Tommy Castles and his wife Shirley ran what Tommy claimed was the first striptease show on the New South Wales circuit. Their biography, as told by Bob Morgan, reveals that life as a travelling showgirl was highly supervised for two reasons: Tommy wanted to keep the boxers away from 'the girls' and Shirley wanted the act to retain some credibility. She therefore checked the girls' caravans three times a night, Morgan explained:

[Shirley] confesses that she may have been considered a strict master but in that way she had good girls and good staff ... The reasoning was that if the girls were seen out up on the town, maybe in pubs or other places, and the next day on the line-up board they were being introduced as 'Fifi the famous fan dancer', the show immediately lost credibility and became a big laugh. ${ }^{25}$

The importance of maintaining the credibility of the girls' identities indicates that this was more than thinly veiled deception in which the audience participated. The Castles made considerable efforts to maintain the façade of this racial theatre.

The use of Pacific Island identities for the girls in the leg shows was common, and was sometimes mixed with generic jungle props. Aboriginal woman Iris LovettGardiner wrote of a variety of leg-shows that she encountered in her time on the showgrounds. Iris was a Gunditjmara woman from western Victoria who travelled with her boxer-husband on the southeastern circuit and worked as a ticket-seller in the 1940s. She recalled particularly Johnny Foster's show in which he had 'Island girls 
with snakes that used to crawl around their bodies and they also had monkeys that were mostly for show'. ${ }^{26}$ Aboriginal sisters Maisie Kelly and Hazel Vale laughed uproariously while telling of the 'hula hula dance' that used to be performed at the Armidale Show in NSW:

HV: Auntie Lil ... used to dance on the stage - she was pretty good ... they came here to Armidale and they were saying oh meet these Fijians from Fiji, or Honolulu, doin the dance and another piece, but she was a McKenzie from up on North Hill. We knew them you see, two dark women, yeah, they said Black Fijians from Armidale, wearing little skirts [laughing obscures the rest of the sentence]. Oh and after the show [more laughing].

Interviewer: They passed themselves off as Hawaiians?

MK: Oh yeah. ${ }^{27}$

The long-held stereotypes of some Pacific Island women as sexually available and alluring were evoked by the shows and acted to conceal, albeit clumsily, Aboriginal women's identities and culture. Several scholars have documented the development of Polynesian fantasies based on literature, explorers' reports and art, and, by the 1930s, Hollywood's creation of the generic South Seas woman. ${ }^{28}$ The influence of movies and other images in popular culture was clear in the various stage acts concocted in sideshows. ${ }^{29}$ Where Aboriginal rough-riders' Aboriginality was sometimes used to explain their skills (they were closer to Nature and hence related well to animals), and Aboriginal boxers' masculinity (related to notions of primitivism) was an integral part of the playing out of racial dominance, Aboriginal women's racial identities were obscurred under those of a mythical and usually quite confused Pacific identity.

There were compelling cultural and historical reasons for this disguise. Histories of frontier conflict in southeastern Australia, of Aboriginal domestic service and the life on missions, and the narratives of women belonging to what has become known as the 'Stolen Generations' are thick with sexual violence against indigenous women at the hands of white men. Evidence of the consequences of racial sexual violence abound in the writings of missionaries and settlers, as well as those Europeans who were sympathetic to the Aboriginal cause. ${ }^{30}$ The 'half-caste menace', with its literal embodiment of sexual connection between white men and indigenous women, had also pre-occupied every group concerned with racial fitness from the 1890s onwards. So full of loathing and disgust were portrayals of Aboriginal women's sexuality in some outlets of popular culture that they can really only be explained by a cultural millstone of shame and self-loathing on the part of whites. Raymond Evans has argued that 'on all Australian colonial frontiers ... Aboriginal women were progressively reduced to a position of extreme dehumanisation in white eyes'. He concludes that '[f]rontier interracial sexual relations thus occurred largely within a context of unfreedom, exploitation and terror' ${ }^{31}$ Consequently it was easier for show audiences to enter into a fantasy of South Seas 'dusky maidens' than to confront the extent to which Aboriginal women and white men had a sexual history and what that history represented for white settler Australians - at best, violent conquest. $^{32}$

Disguise was also a device used by Aboriginal families to keep the state out of their intimate business. From the 1860s onwards with the passage of the first Aboriginal Protection Act in Victoria, indigenous people's lives were increasingly controlled by legislation. Under the guise of protecting and later assimilating Aboriginal people, their employment, movement and wages all came under government control as did the more private aspects of Aboriginal life such as dress, 
marriage and, most notoriously, child-rearing. Many Aboriginal people took the option of disguising their Aboriginality if it was possible. In Sally Morgan's autobiographal novel, My Place, she tells of a childhood encased in deception and disguise. Her grandmother, Daisy, insisted on raising the family as 'Indian'. 33 Historian Peter Read has also observed that it was common in cases of adoption of Aboriginal children removed from their birth families, for adoptive parents to be advised to tell their child they were 'of Asian or Greek or Italian descent and to burn the official papers'. ${ }^{34}$ Another example closer to the home of our leg-show performers was that of 1920s horseman and impresario Bob West, father of some of the best equestrian performers of the 1940s including Kitty Gill (nee West), who 'appeared to "resent" his Aboriginality and concealed his true ethnicity from his children ... telling them they had "Spanish blood"" ${ }^{35}$ Disguise was common in early twentieth-century Aboriginal life for a variety of reasons usually related to avoiding the unwelcome attention of authorities and the general public, thus making life easier for children. The range of circumstances under which disguise was employed, however, speaks to complex meanings of fear, shame, performance and agency.

\section{II}

A comparison of Aboriginal leg-show performers with the performance of hula in the United States can shed some light on Aboriginal women's motives and lives. Adria Imada argues that the performance of hula on the 'imperial hula circuits' of the 1930s and 1940s produced a fantasy of attachment that served to bind mainland America to its colony participating in a twentieth century version of what Tony Ballantyne has referred to as 'strategic intimacies'. ${ }^{36}$ In these more public performances, she argues, 'Hawaiian women produced a feminized version of Hawai' $i$ on stage, offering their aloha - the promise of intimacy, affection, and veneration - to the United States'. ${ }^{37}$ Through the entrepreneurial spirit of some New York hotels that opened 'Hawaiian Rooms', as well as through increasing demand for hula dancers at movie studios, many Hawaiian women made their way to America as performers. These women became minor celebrities: newspapers and gossip columns in magazines reported on their arrival, on their romances and marriages. They were almost never photographed in contemporary Western dress, and were constantly described as having "clear brown skins ... flashing smiles, [with] their beautiful, dark hair and their full yet graceful figures'. ${ }^{38}$ Imada argues that a particular kind of 'Hawaiian-ness' was perfomed on stage: 'docile, ever welcoming, and ever desirable ... signified primarily through the spectacle of women's bodies'. 39 Nonetheless, Imada acknowledges, these performances did represent some continuation with traditional cultures for these women and the male musicians who accompanied them to New York, and, as shall be discussed further below, they also represented a more glamorous life than Hawaiian women could expect if they stayed at home.

Aboriginal women performing as 'hula girls' shared some of the same motives as Hawaiian women. They were not simply objects of desire and fantasy: they had desires of their own. 'Girls' were paid a steady wage in an age when most Aboriginal workers had large proportions - up to $90 \%$ in some cases - of their meagre wages paid directly to the states' Aborigines Boards, supposedly to be held in trust. ${ }^{40}$ These wages were doled out piecemeal by the authorities, and in some cases disappeared altogether. Indigenous performers were out of reach of the various authorities and, from the evidence available about other better-studied members of sideshows, were probably paid the same rates regardless of race. ${ }^{41}$ Living expenses were taken care of in the show 'family', leaving Aboriginal sideshow performers with more discretionary 
funds than others of their race. Against this must be set the reality that Aboriginal women probably had limited opportunities to spend their wages in shops where, by and large, Aboriginal customers were not welcome. ${ }^{42}$

The glamour of performing, such that it was, and the alternative it presented to more prosaic occupations may have also been a drawcard for leg-show performers. It certainly was for dancers on the hula circuit in the United States. Imada argues that hula dancers could earn 'between fifty to one hundred dollars a week, compared with four to ten dollars a week in the pineapple canneries'. ${ }^{43}$ Apart from the canneries, Hawaiian women could seek employment as 'waitresses or domestics - or, if college educated, perhaps as school teachers or secretaries'. The hula circuit 'presented a dream ticket out of Hawai' $i$, promising fame, glamour, and middle-class status difficult for them to achieve in the plantation and service industries'. ${ }^{44}$ Aboriginal women were not aiming for middle-class status, but for transitory relief from being at the bottom of the social and economic heap. By far the most common occupation for Aboriginal women was as domestic servants. ${ }^{45}$ Margaret Tucker, an Aboriginal domestic servant who in later life became a well known activist, had a reputation when a young woman in the late 1920s for her fine singing voice. Her performances were based, as were many at the time, on African-American popular music and included Way down upon the Swanee River, Old Black Joe, and Carry me back to Old Virginny. Popular Hawaiian songs probably also featured in her repetoire. ${ }^{46}$ She was 'much sought after for concerts and entertainments' and while in domestic service performed at the parties of some of Melbourne's elite families. This was a doubleedged sword for Tucker. On the one hand it was 'wonderful fun for a young Aboriginal woman who from childhood had seen her people suffer hurts and indignities and had been too miserable to speak up against them'. But, on the other hand, she knew she 'was just an Aboriginal maid, getting to love parties and all that kind of life stood for'. ${ }^{47}$

White male audience responses to Aboriginal women performers requires some speculation. That female strippers (Aboriginal and non-Aboriginal) exercised power over their male audiences is indisputable, especially it seems over younger men. Australian historian John Lack, who saw the strip-tease artist 'Bubbles' with his mates when they were youths in the $1950 \mathrm{~s}$, 'were panting through the act. It was the first female flesh we had seen'. ${ }^{48}$ Bubbles, a white woman, danced, stripped and took a bubblebath in front of many audiences per day. She usually coaxed an embarrassed onlooker to come and scrub her back. Showie Gail Magdziarz told Richard Broome that while most of the audience were probably married to 'better-looking wives', strip shows were 'like a pressure cooker, it let off a bit of steam, and they could survive on that'. Bernice Kopple, a blue-eyed, blonde Scot nevertheless known as the 'Eastern Snake Girl', stated that the 'spectacle of an attractive girl dancing with, to most people, repulsive reptiles is something men find hard to resist ... Some fellows come to see a show, and stay for hours'. ${ }^{49}$ Audience repsonse to Aboriginal strippers may have been more complex: in a society where a relationship with an Aboriginal woman could be made publicly shameful by the sending of burnt corks to men, the otherworld of the leg show was a mix of exotic fantasy and colonial tableau. ${ }^{50}$ Sexual power and sexual shame may have competed and co-existed.

Aboriginal women's performances then were a mixture of desires. The women themselves worked and lived amidst friends and sometimes relations. They travelled, earned wages and were on the stage. Their performances were also, perhaps, a fantasy of forgetting. Colonial history and current circumstances were erased, temporarily 
forgotten. Aboriginality was obscured in songs, dances and stage identities cobbled together from other cultures.

That Aboriginal women's opportunities and conditions were greater within shows than in other jobs is suggested by inferring from the lives of side-show 'freaks' about whom more is known. Within shows, these performers had greater opportunities for wage-earning and perhaps for a more sociable life than they would otherwise have had in mainstream society. People suffering from disabilites that resulted in extremes of height, limblessness, and other bodily abnormalities were dispayed in sideshows in early twentieth-century Australia as 'Tam Tam the Leopard Man', 'Zimmie the Human Fish' and 'Zandau the Quarter Boy'. Newspapers reported in great depth on their appearance when the shows came to town, and in some cases the 'freaks' were part of civic receptions and free performances in the street. ${ }^{51}$ Broome has argued that freaks in Australian travelling shows were the subjects of paternalistic relationships with their managers. Within these relationships, "power runs both ways' creating complex arrangements of dual agency: 'those above believe they have a duty to rule and care; those below extend deference in return for that protection'. ${ }^{52}$ In an important point that sheds light on the position of leg-show performers, Broome notes that the 'setting of these relationships are important too. The community in which freaks lived and worked, could mitigate oppression as well as express it'. ${ }^{53}$ Aboriginal women's own agency, kin relationships within the show community and paternalistic relationships with impressarios created an environment where, like 'freaks', they could be protected from the worst prejudice of mainstream society.

Historians of theatre and popular culture now regard burlesque performers in the nineteenth century as young women choosing 'leg work' over domestic service, factory work or marriage, as choosing to work in the 'business of theatre'. ${ }^{54}$ In the Australian case, it may well have been that 'leg work' was one of many occupations cobbled together in a working life. Aboriginal girls could be apprenticed into domestic service from the ages of 14 years to 21 years; from there they might move into hotel work and employment as barmaids. ${ }^{55}$ Non-indigenous women also moved between bar work, performance and sex work. On the 1890s Western Australian goldfields, 'hotels paid young women with any pretence at musical ability the handsome sum of $£ 10$ per week to be "musical barmaids", that is to play the piano and sing, in order to attract male custom and keep these customers entertained rather than rowdy'. ${ }^{56}$ At the 1891 inquiry into Chinese gambling, several women gave evidence demonstrating that working class women combined prostitution with factory work, domestic service, bar work, and occasionally the "far more exotic occupation of ballet dancer, then performer of "statues" in Chiarini's circus'. ${ }^{57}$

It is also clear that the 'leg business' changed character between the late $1860 \mathrm{~s}$ and the 1920s. Burlesque, with ribald humour, sketches, cross-dressing and girls in tights, was part of a wide variety of theatrical entertainment available to men and women of all classes in the nineteenth century. Peter Buckley has described American burlesque audiences in the $1870 \mathrm{~s}$ as 'simple and almost homely people ... comfortable, middle-aged women from the suburbs and their daughters' ${ }^{58}$ It was not until the 1920s that strip tease became the mainstay of burlesque shows and it was also during this decade that 'strip tease was relegated to male-only audiences'. 59 Andrea Friedman argues that by the 1930s in New York City, 'legitimate theater drew a middle-class and mixed gender (therefore respectable) audience ... Burlesque, in contrast, catered predominantly to working-class men. ${ }^{60}$ 
There is no indication that leg shows as part of sideshows in Australia were a front for prostitution. Indeed, given that showies had to apply to local municipal authorities in order to be able to occupy space, any hint of prostitution would have been damaging to the business prospects of the entire sideshow. In addition Frances argues that prostitution (of the more formal rather than informal kind) was almost exclusively an urban phemonemon in the early twentieth century. Similarly, leg shows were not caught up in organized crime in the same way that prostitution was in the interwar period. ${ }^{61}$ The tight supervision under which Shirley Castles kept her 'girls' also speaks to a surprisingly chaste environment. Indeed, Friedman argues that it was not sexuality but suggestiveness that was central to burlesque:

Burlesque in the 1930s was organized in particular around the striptease and double entendre, each of which highlighted not sexuality per se but sexual suggestiveness. This suggestiveness gave burlesque an extraordinary capacity for diverse interpretation and, contrary to our stereotype of passive burlesque audiences, requires active viewing. Paradoxically, the centrality of suggestiveness made burlesque's meanings slippery - that is, it made possible the denial of sexual content - at the same time that it highlighted the endorsement of sexual desire that was fundamental to the genre. ${ }^{62}$

\section{III}

Two historiographical problems arise through this attempt to explore the intimate enviroment of the strip tent. The first is that Australian historical research into relationships between indigenous and non-indigenous women and men has focused on particular areas. Histories of interracial intimacy - of consensual and often long-term relationships - have tended to focus on early sealing communities in Tasmania, the cattle frontier of the Northern Territory and the occasional biography of white bush workers whose lives became intermingled with Aboriginal women and their families. ${ }^{63}$ Interracial marriage was often made impossible by legislation designed to protect Aboriginal women from sexual assault and exploitation. From the late nineteenth century it was illegal in Western Australia, the Northern Territory and Queensland for a white man to cohabit with an Aboriginal woman and permission to marry had to be sought from the Aborigines Boards (as was the case for all Aboriginal people even marrying Indigenous partners). ${ }^{64}$ Even within the show community marriage between indigenous and non-indigenous members were unusual: an exception was tent boxer Alick Jackomos, the son of Greek immigrants, who married Merle Morgan (of Yorta Yorta descent) in the 1950s. ${ }^{65}$ The other focus for historians has been on what Ann Laura Stoler characterizes as 'gendered and racialized intimacies of everyday': usually indigenous and non-indigenous women living together in mistress-servant relationships involving shared childcare, companionship, assistance during childbirth and illness. ${ }^{66}$ Increasingly, family histories are emerging as a site where interracial marriage becomes more apparent, albeit on an individual scale and sporadically. ${ }^{67}$

The second historiographical problem concerns the paucity of evidence of indigenous women's performances on the show circuit. Compared with the relatively large amount of evidence that exists in government records of Aboriginal people, what we know of people who lived outside of government control is fragmented and scattered; in the case of Aboriginal leg show performers, it is tempting to ignore what exists as anomalous and insubstantial. The snippets of interesting material that might illuminate the dimly lit interior of the strip tent suffer from the process of writing about them, and in the end the threshold of evidence required in our discipline might 
mean that we discard them in favour of weightier lumps of evidence that enable us to make more substantial claims about the past. However, the lack of evidence that remains about leg shows on the travelling-show circuit, their specific format and their performers and audiences, is to be expected given their transitory nature and their intention as an ephemeral space of fantasy; indeed, the lack of evidence itself tells us something about the nature of these spaces. Leg shows featuring Aboriginal women existed as historical moments deeply iterative of sexual desire and yearnings of other sorts.

Within the tents of sideshows was a multi-racial world of body display ranging from the respectable, open-air performances of rodeo riders to the less orthodox and titillating 'freaks'. Even more shadowy was the world of the leg-show performers, where white male audiences and a multi-racial cast of women met in performances of desire and fantasy. The show world operated outside of the mainstream, away from the institutions designed to control indigenous life, and largely in contravention of laws that excluded indigenous people from equal pay and conditions, and that controlled most aspects of their private lives. Showies could not avoid the wider world however, and narratives of disguise sometimes extended into 'real' life. The glimpses of the intimate space of the leg-show tent therefore provides hints, suggestions and partial revelations of complex relationships and competing desires.

\footnotetext{
${ }^{1}$ See for example, Karen Crook, 'The Politics of Influence: the Work of the Country Women's Association of Victoria Incorporated in the Public Sphere', PhD thesis, University of Melbourne, 1997; Kathryn M. Hunter, Father's Right-Hand Man: Women on Australia's Family Farms in the Age of Federation, 1880s to the 1920s, Melbourne, 2004.

${ }^{2}$ See for example Joanne Scott and Ross Laurie, 'Colonialism on Display: Indigenous People and Artefacts at an Australian Agricultural Show', Aboriginal History, 31 (2007), pp.45-62.

${ }^{3}$ Brisbane Courier, 28 September 1931, p.10.

${ }^{4}$ Richard Broome and Alick Jackomos, Sideshow Alley, St Leonards, 1998.

${ }^{5}$ Queenslander, 22 August 1929, p.57.

${ }^{6}$ Don Walker, pers. comm., 2001.

${ }^{7}$ Raelene Frances, Selling Sex: A Hidden History of Prostitution, Sydney, 2007, p.46.

${ }^{8}$ Geoffrey Elton, cit. Judith Allen, Sex \& Secrets: Crimes Involving Australian Women Since 1880, Melbourne, 1990, pp.10, 2.

${ }^{9}$ See for example photographs of crowds at the Walgett Show in 1934, At Work \& Play 0313, State Library of New South Wales (accessed through www.pictureaustralia.org); reminiscences of leg-show performers in Broome and Jackomos describe white male audiences for their shows, pp.67-8. The population profile of Victoria and southern NSW by the turn of the twentieth century was overwhelmingly European, especially in rural areas but in northern NSW and southern Queensland slightly less so. The difficulties and debates about Aboriginal population data are thoroughly discussed in Len Smith, Janet McCalman, Ian Anderson, Sandra Smith, Joanne Evans, Gavan McCarthy, Jane Beer, 'Fractional Identities: The Political Arithmetic of Aboriginal Victorians', Journal of Interdisciplinary History, 38, 4 (2008), pp.533-51.

${ }^{10}$ See for example Billy Crawford interviewed by Chris Sullivan, 1989, Chris Sullivan Collection, TRC2750/569, National Library of Australia (NLA); Bill Gray
} 
interviewed by Chris Woodland, 1993, TRC3002/1, NLA; Clarry Grogan interviewed by Kevin Bradley and Peter Ellis, 1990, TRC2604, NLA.

${ }^{11}$ Richard Broome, Aboriginal Victorians, St Leonards, 2005, p.254.

${ }^{12}$ For a state-by-state analysis of this process see Ann McGrath, ed., Contested

Ground: Australian Aborigines under the British Crown, St. Leonards, 1995.

${ }^{13}$ See Russell McGregor, Imagined Destinies: Aboriginal Australians and the Doomed Race Theory, 1880-1939, Carlton, 1997.

${ }^{14}$ Joyce Ingram in Stuart Rintoul, The Wailing: A National Black Oral History, Melbourne, 1993, p.20.

${ }^{15}$ Human Rights commissioners hearing evidence into the inquiry into the removal of Aboriginal children from their families remarked that sexual violence was a consistent theme throughout. Much of this evidence is reported in Bringing Them Home: Report of the Inquiry into the Removal of Aboriginal and Torres Strait Islander Children from their Families, Canberra, 1997.

${ }^{16}$ See for example Heather Goodall's discussion on 'dual occupation' in her Invasion to Embassy: Land in Aboriginal Politics in New South Wales, 1770-1972, St Leonards, 1995, ch.5.

${ }^{17}$ See Broome, Aboriginal Victorians for chapters on campers and city life.

${ }^{18}$ There are several versions of this in Australia: what began as 'bush carnivals' became known as buckjump competitions and then, by the 1930s, were generally known by the American term 'rodeo'. See Jenny Hicks, Australian Cowboys, Roughriders and Rodeos, Pymble, 2000. On Aboriginal rough riders, see Kathryn M. Hunter, 'Rough riding: Aboriginal participation in Australia's travelling shows to the 1950s', Aboriginal History, 32 (2008), pp.82-96.

${ }^{19}$ See the work of Richard Broome, 'Theatres of Power: Tent Boxing Circa 19101970', Aboriginal History, 20 (1996), pp.1-23.

${ }^{20}$ Broome, 'Theatres of Power'.

${ }^{21}$ On both of these points see Hunter, 'Rough riding'. See also Henry Reynolds, With the White People, Ringwood, 1990 and Ann McGrath, Born in the Cattle: Aborigines in Cattle Country, Sydney, 1987.

22 Jim Ridgeway and Jim Lowden, Rodeo at Lang Lang, Kilmore, 1976, p.59. Richard Broome identifies one version of 'Vanessa the Undresser' as Vanessa Lee from Tennessee. See Broome and Jackomos, p.67

${ }^{23}$ James Osram, The Last Showman: Larry Delahunty's Larrikin Life, Chippendale, 1992, p.7.

${ }^{24}$ Angela Badger, The Boy from Bunningyong: The Life of an Australian Showman, Melbourne, 1993, pp.67-68.

${ }^{25}$ Bob Morgan, The Showies, privately published, 1995, p.36.

${ }^{26}$ Iris Lovett-Gardiner, The Lady of the Lake: Aunty Iris's Story, Melbourne, 1997, p.67.

${ }^{27}$ Maisie Kelly and Hazel Vale (nee Archibald), interviewed by Chris Sullivan, 1990. Chris Sullivan Collection, TRC2750/556, NLA. Maisie and Hazel are descendants of the New England groups Nganyaywana, Dainggatti and Gumbainggir.

${ }^{28}$ See Ann McGrath, 'The White Man's Looking Glass', Australian Historical Studies, 24, 95 (1990), pp.189-206; Bernard Smith, European Vision in the South Pacific, 1768-1850, Oxford, 1960; Sean Brawley and Chris Dixon, 'Searching for Dorothy Lamour: War and Sex in the South Pacific, 1941-45', Australasian Journal of American Studies, 18, 1 (1999), pp.3-18 in which they make a clear distinction between American servicemen's experiences in 'Polynesia' and those in 'Melanesia', 
arguing that Hollywood's generic 'South Seas maiden' was more likely to be found in Polynesian societies.

${ }^{29}$ DeSoto Brown, for example, writes of an upsurge in the use of idealized Hawaiian images in advertising in the interwar period, in 'Beautiful, Romantic Hawaii: How the Fantasy Image Came to Be', Journal of Decorative and Propaganda Arts, 20 (1994), pp. 252-71.

${ }^{30}$ See for example missionaries' writings in John Harris, One Blood: 200 Years of Aboriginal Encounter with Christianity: A Story of Hope, Sutherland, 1990; writings of first wave feminists such as Louisa Lawson in Patricia Grimshaw, Marilyn Lake, Ann McGrath and Marian Quartly, Creating a Nation, Ringwood, 1994; settler accounts also often commented on either the very few numbers of children among Aboriginal groups (infertility caused by venereal disease), or on the violence they witnessed. See for example, Henry Reynolds, The Other Side of the Frontier, Ringwood, 1982; Jan Critchett, A Distant Field of Murder, Carlton, 1990.

${ }^{31}$ Raymond Evans, "'Don't You Remember Black Alice, Sam Holt?"' in Raymond Evans, Fighting Words: Writing About Race, St Lucia, 1999, pp.201, 204.

${ }^{32}$ See for example, Raelene Frances' discussion of Aboriginal 'prostitution' in her book Selling Sex; see also Grimshaw et al., Creating a Nation; Reynolds, The Other Side of the Frontier.

${ }^{33}$ Sally Morgan, My Place, Fremantle, 1987, p.97ff.

${ }^{34}$ Peter Read, A Rape of the Soul So Profound, St Leonards, 1999, p.37.

${ }^{35}$ Mark St Leon, 'Celebrated at First, then Implied and Finally Denied: The Erosion of Aboriginal Identity in Circus, 1851-1960', Aboriginal History, 32 (2008), pp.6381, quotation on p.75.

${ }^{36}$ Tony Ballantyne, 'Intimacy, Knowledge and Colonization: Thinking Through Southern New Zealand', unpublished conference paper, Interracial Intimacies: New Zealand Histories symposium, University of Otago, 19-20 June 2009.

${ }^{37}$ Adria L. Imada, 'Hawaiians on Tour: Hula Circuits Through the American Empire', American Quarterly, 56, 1 (2004), pp.111-49, quotation on p.114.

${ }^{38}$ New York World Telegram, nd, cit. Imada, p.131.

${ }^{39}$ ibid., p.134.

${ }^{40}$ For figures on wages see, Rosalind Kidd, Trustees on Trial: Recovering the Stolen Wages, Canberra, 2007, pp.61-62.

${ }^{41}$ Professional Aboriginal roughriders were paid equally to whites in the troupe and Richard Broome found no evidence of large wage differences between performers in the 'freak shows'. See Hunter, 'Rough riding' and Richard Broome, 'Not Strictly Business: Freaks and the Australian Showground World', Australian Historical Studies, 40, 103 (2009), pp.323-42.

${ }^{42}$ Furley Gardener who grew up on isolated Cape Barren Island (Tasmania) was shocked when she went to Launceston for work and she and her friend were refused service in shops and hotels: 'We thought our world was crumbling'. See Furley Gardner in Rintoul, p.218.

${ }^{43}$ Imada, p. 130.

${ }^{44}$ ibid., pp.126, 130.

45 Jackie Huggins and Thom Blake, 'Protection or Prosecution? Gender Relations in the Era of Racial Segregation', in Kay Saunders and Raymond Evans, eds, Gender Relations in Australia: Domination and Negotiation, Sydney, 1992, pp.50-2.

${ }^{46}$ Margaret Tucker mentions wearing 'hula' costumes in her autobiography, If Everyone Cared: The Autobiography of Margaret Tucker, Melbourne, 1977, p.164. 
47 ibid., p. 163.

${ }^{48}$ John Lack cited in Broome and Jackomos, p.68.

${ }^{49}$ Gail Magdziarz and Bernice Kopple in Broome and Jackomos, pp.68, 67.

${ }^{50}$ McGrath, Born in the Cattle, p.70ff.

${ }^{51}$ See Broome and Jackomos, Sideshow Alley.

${ }^{52}$ Broome, 'Not Strictly Business', p. 331.

${ }^{53}$ ibid., p.328.

${ }^{54}$ Lillian Schlissel, ‘A Long View of Burlesque', American Quarterly, 46, 1 (1994), p. 103 .

${ }^{55}$ On Aboriginal women and bar work see Jackie Huggins, 'White Aprons, Black Hands: Aboriginal Women Domestic Servants in Queensland', Labour History, 69 (1995), p.189.

${ }^{56}$ Frances, p.67. Diane Kirkby, Barmaids: A History of Women's Work in Pubs, Melbourne, 1997.

${ }^{57}$ Frances, p. 123.

${ }^{58}$ Peter Buckley, 'The Culture of "Leg-work": The Transformation of Burlesque After the Civil War', in James Gilbert, ed., The Mythmaking Frame of Mind: Social Imagination and American Culture, Belmont, 1993, pp.122, 126. Schlissel, p.102. ${ }^{59}$ Schlissel, p.104; Andrea Friedman, "The Habitats of Sex-crazed Perverts": Campaigns Against Burlesque in Depression-era New York City', Journal of the History of Sexuality, 7, 2 (1996), p.208.

${ }^{60}$ Friedman, p.207.

${ }^{61}$ See Frances, Selling Sex.

${ }^{62}$ Friedman, p.208.

${ }^{63}$ See for example Lyndall Ryan, Aboriginal Tasmanians, St Lucia, (1981) 1996;

McGrath, Born in the Cattle; and Daryl Tonkin and Carolyn Landon, Jackson's Track, Ringwood, 2000.

${ }^{64}$ McGrath, Born in the Cattle; Ann McGrath, 'Shamrock Aborigines: the Irish, the Aboriginal Australians and their Children', Aboriginal History, 34 (2010), pp.55-84. ${ }^{65}$ Richard Broome with Corinne Manning, A Man of All Tribes: Alick Jackomos, Canberra, 2006.

${ }^{66}$ Ann Laura Stoler, 'Tense and Tender Ties: the Politics of Comparison in North American History and (Post) Colonial Studies', The Journal of American History, 88, 3 (2001), p.864. For examples of this work in Australia see biographies, autobiographies and fiction such as Jeannie Gunn, We of the Never-Never, London, 1920, or the work of Anna Cole, Victoria Haskins and Fiona Paisley, eds, Uncommon Ground: White Women in Aboriginal History, Canberra, 2005. See also histories of white women activists who befriended Aboriginal leaders, for example Liz Reed, " "Mrs Bon's verandah full of Aboriginals": Race, Class, Gender and Friendship', History Australia, 2, 2 (2005), pp.39.1-39.15.

${ }^{67}$ See for example McGrath's own family history that she recounts in 'Shamrock Aborigines', or eminent Australian historian Henry Reynolds who now believes that the circumstantial evidence points to his grandmother being of Aboriginal descent. See Sydney Morning Herald, 26 August 2005. 